\title{
Thyroid Dysfunction Following Supraclavicular Irradiation in the Management of Carcinoma of the Breast
}

\author{
Serap AKYUREK ${ }^{1}$, Ibrahim BABALIOGLU ${ }^{1}$, Kenan KOSE ${ }^{2}$, Saban C. GOKCE ${ }^{1}$ \\ ${ }^{1}$ Ankara University Faculty of Medicine, Department of Radiation Oncology \\ ${ }^{2}$ Ankara University Faculty of Medicine, Department of Biostatistic, Ankara, TURKEY
}

\begin{abstract}
Radiation induced thyroid dysfunction is usually underestimated in patients with breast cancer who had supraclavicular irradiation (RT). In the present study, a total of 28 patients with breast cancer received supraclavicular RT were evaluated focusing on radiation dose-volume factors in relation to thyroid function. Thyroid function tests, including serum thyroid stimulating hormone, free thyroxine, free triiodothyronine, were analyzed prior to RT and 3, 6, 9, 12, 18 and 24 months after RT. Based on each patient's dose volume histogram (DVH), total volume of the thyroid, mean radiation dose the thyroid and percentages of thyroid volume which received radiation doses 10-50 Gy (V10-V50) were considered for statistical analysis. The median follow-up time was 25 months (range, 12.3-36 months). Of 28 patients 6 (21\%) were diagnosed with hypothyroidism (HT). The median time to the development of HT was 9 months (range: 3-18 months). Mean thyroid dose was 31 Gy $(19-48$ Gy) and mean thyroid volume was $32 \mathrm{cc}(12-64 \mathrm{cc})$. We found that $\mathrm{V} 20(\mathrm{OR}=10,95 \% \mathrm{Cl}=1.15-86.88$, $\mathrm{p}=0.05)$, $\mathrm{V} 30(\mathrm{OR}=10,95 \% \mathrm{Cl}=1.15-86.88, \mathrm{p}=0.05)$ and $\mathrm{V} 40(\mathrm{OR}=21,95 \% \mathrm{Cl}=1.61-273.34, \mathrm{p}=0.02)$ and mean thyroid dose $\geq 36$ Gy $(\mathrm{OR}=10,95 \% \mathrm{Cl}=1.15-86.88)(\mathrm{p}=0.05)$, had a significant impact on development of HT. Moreover, significant elevation was observed in mean TSH level between baseline ( $1.85 \pm 1.47 \mathrm{mlU} / \mathrm{L})$ and at 6 months $(3.80 \pm 7.42 \mathrm{mlU} / \mathrm{L}),(p=0.003)$. Supraclavicular RT in patients with breast cancer appear to amplify the risk of $\mathrm{HT}$. We believe further investigations in larger cohort are required to confirm our results.
\end{abstract}

Keywords: Thyroid dysfunction, Breast Cancer, Radiotherapy

\section{ÖZET}

\section{Meme Kanserinde Supraklavikuler Işınlama Sonrası Tiroid Fonksiyon Bozukluğu}

Supraklavikuler radyoterapi (RT) alan meme kanserli hastalarada tiroid fonksiyon bozuklukları genellikle göz ardı edilir. Bu çalışmada supraklavikuler RT alan 28 meme kanserli hasta, radyasyon doz-volüm faktörleri ve tiroid fonksiyon testlerine fokuslanarak değerlendirildi. Tiroid stümülan hormon, serbest triiyodotironin, serbest tiroksin, RT'den önce ve 3, 6, 9,12,18 ve 24 sonra analiz edildi. Tüm hastaların doz-volüm histogramlarına (DVH) dayanarak total tiroid volümü, mean tiroid dozu ve 10-50 Gy radyasyon alan tiroid volüm yüzdesi (V10-50) istatiksel analiz için elde edildi. Ortalama takip süresi 25 aydı (12.3-36 ay). Yirmisekiz hastanın 6 (\%21)'sında hipotiroidizm (HT) saptandı. Median HT gelişme zamanı 9 (3-18 ay) aydı. Mean tiroid dozu 31 Gy (19-48 Gy) ve mean tiroid volümü 32 cc (12-64 cc) idi. V20 (OR=10, 95\% $\mathrm{Cl}=1.15-86.88, \mathrm{p}=0.05), \mathrm{V} 30(\mathrm{OR}=10,95 \% \mathrm{Cl}=1.15-86.88, \mathrm{p}=0.05)$ ve $\mathrm{V} 40(\mathrm{OR}=21,95 \% \mathrm{Cl}=1.61-273.34, \mathrm{p}=0.02)$ ile mean tiroid dozunun $\geq 36$ Gy $(\mathrm{OR}=10,95 \% \mathrm{Cl}=1.15-86.88)(\mathrm{p}=0.05)$ olması $\mathrm{HT}$ gelişiminde anlamlı bulundu. Ek olarak, bazal mean TSH (1.85 \pm 1.47

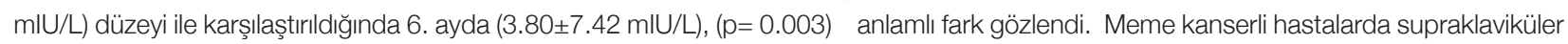
RT, HT riskini artırıyor görünmektedir. Sonuçlarımızın daha fazla hasta sayılı çalışmalar ile desteklenmesi gerektiğine inanmaktayız.

Anahtar Kelimeler: Tiroid disfonksiyonu, Meme Kanseri, Radyoterapi 


\section{INTRODUCTION}

Thyroid dysfunction is a well-known late effect after radiotherapy (RT) to the neck region in patients with head and neck cancers. ${ }^{1-4}$ In such patients, the whole gland is usually located with in the high-dose level of radiation fields but little has been studied in breast cancer patients receiving RT to the supraclavicular field that involves part of thyroid gland inevitably included in the RT portals.

Of the different types of radiation-induced thyroid dysfunction, subclinical hypothyroidism (HT) is the most common, this is followed by clinical HT. Subclinical HT is defined biochemically as a normal free serum thyroxine hormone (fT4) level in the presence of an elevated thyroid stimulating hormone (TSH), with no clinical symptoms, whereas clinical HT is characterized by a high serum TSH level and low fT4 level, in which patient may present with clinical sypmptoms such as weight gain, fatigue, slow mentation and cold intolerance. Hypothyroidism after RT develops at a median interval of 1.4-1.8 years, but it has been reported even 3 months or 20 years after $\mathrm{RT}^{2,3,5}$

The tolerance dose of the thyroid gland has not been definitively determined. ${ }^{6}$ With conventional fractionation, the critical absorbed dose for radiation induced HT has been estimated to vary between 26 to $40 \mathrm{~Gy} .{ }^{7,8}$ In the Quantitative Analysis of Normal Tissue Effects in the Clinic (QUANTEC) report, dose-volume data for HT were not included. ${ }^{9}$ Some authors suggest that the percentage of thyroid volume receiving $\geq 30 \mathrm{~Gy}$ (V30) is a possible predictor of HT. ${ }^{10,11}$ To date, a clear threshold dose or dose-volume factors for the development of radiation induced HT has not yet been determined.

This study was undertaken to investigate radiation induced thyroid dysfunction in patients with breast cancer receiving RT to the supraclavicular field in relation to total dose and irradiated volume of the thyroid gland by assessing thyroid function before and regular intervals after RT.

\section{MATERIALS AND METHODS}

\section{Patients and Characteristics}

Between October 2010 and December 2012 a total of 28 patients with breast cancer received supraclavicular irradiation were evaluated. Exclusion criteria were: 1) patients with primary thyroid disease, 2) thyroid surgery 3 ) previous RT at another facility that might have included the hypothalamic-pituitary axis or lower neck nodes.

\section{Radiotherapy}

All patients treated with 3 or 4 -field 3D conformal RT (3D-CRT) in which the target volume included the breast or the chest wall and the ipsilateral supraclavicular field (Figure 1-3). The RT planning was based on computerized tomography (CT) scans covering the region from cricoid cartilage to $5 \mathrm{~cm}$ below the clinically marked inferior port edge. CT slice thickness and pitch was $0.5 \mathrm{~cm}$. The clinical target volume, both lungs, heart, contralateral breast and the thyroid gland were delineated by the same radiation oncologist. Treatment planning and dose calculation were performed using the Eclipse (version 10) or Precise Plan planning system. Treatment delivered with Varian Clinac DHX or Electa Synergy Platform linear accelerator with the photon beams energy was $6 \mathrm{MV}$ and/or $18 \mathrm{MV}$. The total dose of $50 \mathrm{~Gy}$ in 25 fractions was given to the breast/chest wall and the ipsilateral supraclavicular field. Nine of the patients received an additional $10 \mathrm{~Gy}$ to the tumor bed. Based on each patient's dose volume histogram (DVH), total volume of the thyroid, mean radiation dose to the thyroid and percentages of thyroid volume which received radiation doses 10-50 Gy (V10-V50) were considered for statistical analysis.

\section{Thyroid Function Tests}

Thyroid function tests consisting of a baseline serum thyroid stimulating hormone (TSH, reference range 0.34-5.60 mIU/L), free triiodothyronine (fT3, reference range 3.8-6 pmol/L), free thyroxine (fT4, reference range 7-16 pmol/L were analyzed prior to RT and every three months the first year and then 18 month, and finally 24 month after RT. A diagnosis of HT was based on TSH value grater than the maximum value of laboratory range and/or fT3 and/or fT4 values lower than the minimum value of laboratory range, regardless of whether any symptom was present.

\section{Statistical Analysis}

Statistical analysis was performed with a Statistical Package for the Social Scienses for Windows (SPSS, version 11.5, Chicago, IL). All values are expressed 


\begin{tabular}{|c|c|}
\hline Characteristic & Patients \\
\hline Number of patients & 28 \\
\hline \multicolumn{2}{|l|}{ Sex } \\
\hline Male & 1 \\
\hline Female & 27 \\
\hline \multicolumn{2}{|l|}{ Age } \\
\hline Median & 50 \\
\hline Range & $(32-75)$ \\
\hline \multicolumn{2}{|l|}{ Stage } \\
\hline$\|$ & 17 \\
\hline III & 11 \\
\hline \multicolumn{2}{|l|}{ Surgery } \\
\hline MRM & 19 \\
\hline $\mathrm{BCT}$ & 9 \\
\hline \multicolumn{2}{|l|}{ Radiotherapy } \\
\hline 50 Gy & 19 \\
\hline $50+10$ Gy & 9 \\
\hline \multicolumn{2}{|l|}{ Chemotherapy } \\
\hline FEC & 8 \\
\hline $4 \mathrm{AC}+4 \mathrm{~T}$ & 20 \\
\hline \multicolumn{2}{|l|}{ Hormonotherapy } \\
\hline Tamoxifen & 19 \\
\hline Aromatase inhibitor & 7 \\
\hline Unknown & 2 \\
\hline \multicolumn{2}{|c|}{$\begin{array}{l}\text { Abbrevations: } \mathrm{MRM}=\text { modified radical mastectomy, } \mathrm{BCT}= \\
\text { breast-conserving therapy, } \mathrm{FEC}=5 \text {-fluouracil, epirubicin, cy- } \\
\text { clophosphamide, } \mathrm{AC}=\text { adriamycin, cyclophosphamide, } \mathrm{T}= \\
\text { paclitaxel }\end{array}$} \\
\hline
\end{tabular}

as means and Standard deviations (SD). Pretreatment TSH, fT4 and fT3 values were compared with the corresponding values obtained after treatment by Wilcoxon test, paired t test and repeated measure- ment of two way ANOVA with repeated measures. Categorical data were analyzed by using Chi-square and Fisher-Exact test. Dosimetric parameters and their association with HT was assessed by univariate logistic regression analysis. $\mathrm{P}$ values $<0.05$ were considered to indicate statistical significance.

\section{RESULTS}

The median follow-up time was 25 months (range, 12,3-36 months). Demographic information for all patients is summarized in Table 1.

Of 28 patients $6(21 \%)$ were diagnosed with hypothyroidism (HT), 2 (7\%) cases had subclinical HT and $4(14 \%)$ cases had clinical HT. The median time to the development of HT was 9 months (range, 3-18 months). Patients who had HT were also screened for antithyroglobulin and antimicrosomal antibodies, antibody titers did not positive in any of these patients. Patients diagnosed clinical HT referred to endocrine department and they received thyroid hormone replacement therapy.

Table 2 shows the mean $( \pm \mathrm{SD})$ for each thyroid function test before and after completion of RT, 3, 6, 9, 12, 18 and 24 months, respectively. Mean baseline TSH level was $1.85 \pm 1.47 \mathrm{mIU} / \mathrm{L}$. The difference in TSH level between baseline and 3 months (mean TSH: $2.01 \pm 1.65 \mathrm{mIU} / \mathrm{L}, \mathrm{p}=0.28$ ) was not significant. However, significant elevation was observed at 6 months (mean TSH: $3.80 \pm 7.42 \mathrm{mIU} / \mathrm{L}, \mathrm{p}=0.003$ ). There was a significant decrease in the mean fT4 levels after the third month on completion of RT compared with baseline levels $(\mathrm{p}=0.004)$ and then relatively become stable. Mean fT3 level showed steady throughout the study period.

Mean thyroid dose, volume and percentage of thyroid gland volume absorbing V10-50 were analyzed acording to DVHs. Mean thyroid dose was 31 Gy (19-48 Gy) and mean thyroid volume was $32 \mathrm{cc}$ (12-64 cc).

Table 2. The mean $( \pm S D)$ for each thyroid function test before and after completion of $R T, 3,6,9,12,18$ and 24 months

\begin{tabular}{|llllllll|}
\hline & Baseline & $\mathbf{3}$ months & $\mathbf{6}$ months & $\mathbf{9}$ months & $\mathbf{1 2}$ months & $\mathbf{1 8}$ months & $\mathbf{2 4}$ months \\
\hline TSH & $1.8 \pm 1.47$ & $2.01 \pm 1.65$ & $3.80 \pm 7.42$ & $3.73 \pm 4.82$ & $3.29 \pm 3.49$ & $5.60 \pm 6.92$ & $4.23 \pm 3.72$ \\
fT3 & $4.71 \pm 0.48$ & $4.6 \pm 0.55$ & $4.79 \pm 0.95$ & $4.63 \pm 0.69$ & $4.71 \pm 0.73$ & $4.35 \pm 0.63$ & $4.74 \pm 0.53$ \\
fT4 & $10.82 \pm 1.76$ & $9.91 \pm 1.82$ & $10.30 \pm 4.07$ & $9.56 \pm 1.37$ & $9.45 \pm 1.76$ & $8.76 \pm 2.09$ & $9.58 \pm 2.01$ \\
\hline
\end{tabular}




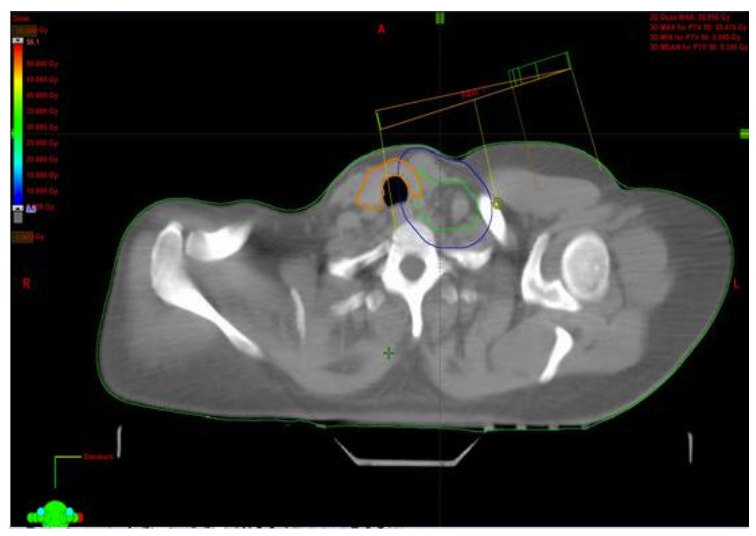

Figure 1. Radiation dosimetric plan for supraclavicular field. The thyroid gland is orange coloured.

Median values of V10-20-30-40-50 were $68 \%, 59 \%$, $57 \%, 55 \%$ and $47 \%$, respectively. We found that V20 $(\mathrm{OR}=10,95 \% \mathrm{CI}=1.15-86.88, \mathrm{p}=0.05), \mathrm{V} 30(\mathrm{OR}=$ $10,95 \% \mathrm{CI}=1.15-86.88, \mathrm{p}=0.05)$ and $\mathrm{V} 40(\mathrm{OR}=21$, 95\% CI=1.61-273.34), $(\mathrm{p}=0.02)$ and mean thyroid dose $\geq 36$ Gy $(\mathrm{OR}=10,95 \% \mathrm{CI}=1.15-86.88),(\mathrm{p}=$ 0.05 ) had a significant impact on development of HT. However, mean volume of thyroid was not associated with development of HT ( $\mathrm{p}=0.99)$.

\section{DISCUSSION}

Our results demonstrated that overall incidence of HT was $21 \%$ in patients with breast cancer who had supraclavicular RT. The median time to the development of HT was 9 months (range, 3-18 months). Radiation induced HT in patients with breast cancer has been investigated in only a few studies. ${ }^{12-14}$ According to these studies, the incidence of HT varies $6 \%$ and $21 \%$ similar to our study. Bruning et al. concluded that HT was significantly more frequent in patients with breast cancer who had received RT to supraclavicular field to non-irradiated breast cancer patients. ${ }^{14}$

Our best of knowledge, only a few investigators have performed clinical DVHs analysis for thyroid dysfunction after RT. ${ }^{8,10,15-18}$ Most of theses studies concerned head and neck cancer patients treated with RT doses higher than those used in RT for breast cancer. In these studies, different dose-volume parameters were used and no baseline assessments of thyroid function were available. Additionally, there was no consistency with regard to follow-up protocol at specified time points. In this study TSH, fT4 and fT3 were monitored prior to RT and regular intervals

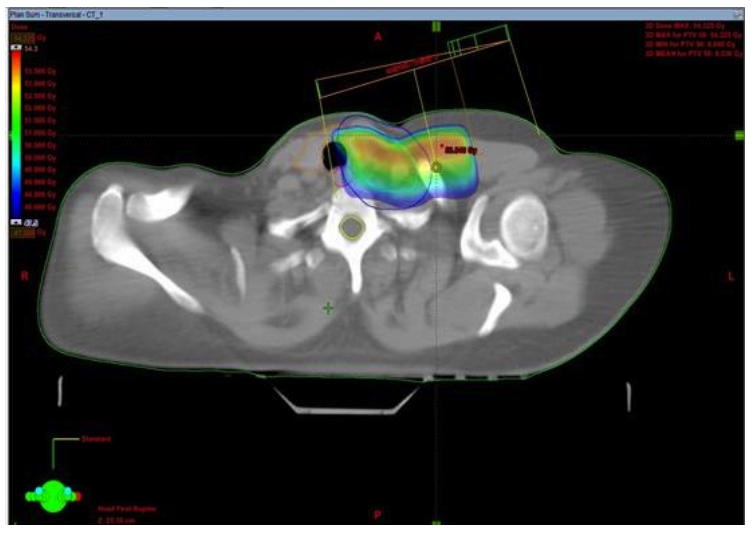

Figure 2. Dose distrubition for supraclavicular field.

after RT with a standardized follow-up protocol. We found V20-40 (thyroid volume receiving over 20-40 Gy) and mean thyroid dose $\geq 36$ Gy had a significant impact on development of HT. Yoden et al. also used DVHs to evaluate the correlation between percentage of the thyroid gland volume absorbing a defined dose and thyroid function. ${ }^{11}$ They found that V10, V20 and V30 have significant impact on the peak level of serum TSH and seemed to be possible risk factor for HT. Similarly, Cella et al. reported the V30 was the only independent predictive factor for HT. ${ }^{10}$ In other 2 studies, that DVHs and percentage of thyroid gland volume absorbing V10-60, Dmin, Dmax were determined. Both of the study revealed that this dosevolume parameters were not associated with HT. ${ }^{15,18}$ However, recent studies published a normal tissue complication probability (NTCP) model based on mean thyroid dose and thyroid volume for radiation induced HT in patients with head and neck cancer. ${ }^{19,20}$ According to these studies, thyroid gland volume and mean thyroid dose were the only independent risk factors for HT. We think that, these NTCP model studies need to support more clinical data.

In our study, mean TSH levels did not change in the first 3 months however after 6 months significantly higher than baseline levels. Additionaly mean fT4 levels showed decreasing at 3 months and then relatively become stable. These finding implied that the majority of change in thyroid function within 6 months after RT. Other reports similarly indicate that radiation-induced changes in thyroid function initially manifested within 3 to 6 months after RT. ${ }^{21-23}$

The time to development of HT has not been con- 


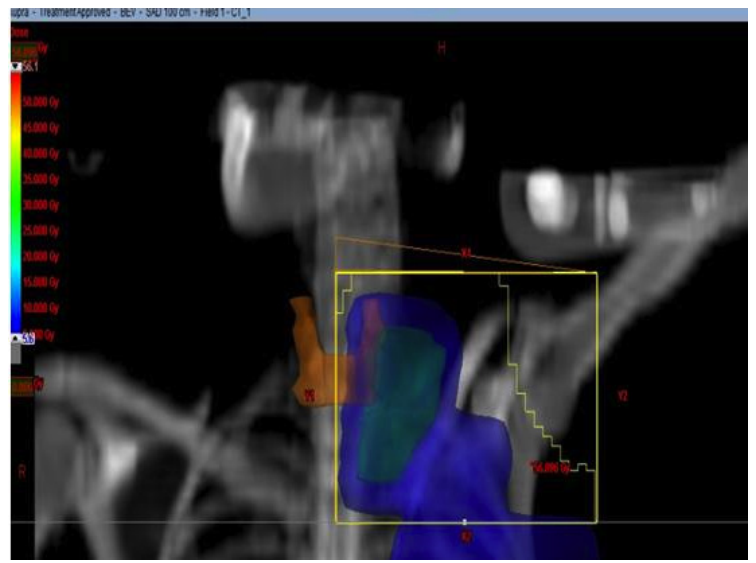

Figure 3. Digital reconstructed image of supraclavicular field. The thyroid gland is orange coloured.

clusively defined. Prospective trials have been conducted in an attempt to answer this question. . $^{1,524-26}$ As stated in these trial, the median time to development of HT appears to range from 1.4 years to 1.8 years. ${ }^{2,5}$ Latency has been observed as soon as 2 to 3 months and as late as 20 years. ${ }^{2,3,23}$ In our study the median follow-up time was 25 months (range, 12,336 months) and the median time to the development of HT was 9 months (range: 3-18 months). Some of the studies suggest longer follow up period after RT because of an increase in the cumulative incidence beyond two years of completion of RT. Mercado et al. described the incidence of HT was $48 \%$ at 5 years and $67 \%$ at 8 years. ${ }^{5}$ Results of our analysis also produced correlation between follow-up duration and incidence of HT that $14 \%$ at 12 months and $21 \%$ at 24 months. In our institute, we continue to monitor all patients who had neck irradiation routinely for thyroid function in their follow-up visit.

The impact of the chemotherapy and endocrine treatments to the development of HT in breast cancer patients have been showed in several studies..$^{12,14,21,27}$ However, some studies suggest that addition of chemotherapy does not increase the risk of development of HT. ${ }^{4,5,25,28}$ In review, Jereczek-Fossa stated that the impact of chemotherapy and endocrine treatments on the risk of HT is still controversial. ${ }^{6}$ In our study, all of our patients received both chemotherapy and RT so we could not evaluate the impact of each treatment separately.

Different treatment techniques may cause higher RT doses to thyroid gland if the dose is not constrained.
Diaz et al. reported on an apparent higher incidence and shorter latency of post-treatment HT with intensity modulated RT (IMRT) compared with 3D-CRT. ${ }^{15}$ This was contributed to higher dose to the thyroid gland with IMRT reference to 3D-CRT. Contouring the thyroid gland as an IMRT avoidance structure, resulted in a significantly lower median thyroid gland dose as compared with 3D-CRT. In our study all patients treated with 3 or 4 field 3D-CRT.

We observed a marked increase in the development of HT in patients with breast cancer following supraclavicular RT. Our finding implied that the majority of changes in thyroid function initially manifested within 3 to 6 months after RT. We found mean thyroid dose $\geq 36$ Gy and V20-40 had a significant impact on the development of HT. Because of the risk of HT, in such patients, thyroid function should be evaluated periodically. However, we believe further investigations in larger cohort are required to confirm our results.

\section{REFERENCES}

1. Colevas AD, Read R, Thornill J, et al. Hypothyroidism incidence after multimodality treatment for stage III-IV squamous cell carcinomas of the head and neck. Int J Radiat Oncol Biol Phys 51: 599-604, 2001.

2. Hancock SL, Cox RS, McDougall IR. Thyroid diseases after treatment of Hodgkin's disease. N Eng J Med 325: 599-605, 1991.

3. Tell R, Lundell G, Nilsson B, et al. Long-term incidence of hypothroidism after radiotherapy in patients with head and neck cancer. Int J Radiat Oncol Biol Phys 60: 395-400, 2004.

4. Grande C. Hypothyroidism following radiotherapy for head and neck cancer: Multivariate analysis of risk factors. Radiother Oncol 25: 31-36, 1992.

5. Mercado G, Adelstein DJ, Saxton JP, et al. Hypothyroidism, a frequent event after radiotherapy and after radiotherapy with chemotherapy for patients with head and neck carcinoma. Cancer 92: 2892-2897, 2001.

6. Jereczek-Fossa BA, Alterio D, Jassem J, et al. Radiotherapy induced thyroid disorders. Cancer Treat Rev 30: 369-384, 2004.

7. Monnier A. Late effects of ionizing radiations on the thyroid gland. Cancer Radiother 1: 717-731, 1997.

8. Kuten A, Lubochitski R, Fishman G, et al. Postradiotherapy hypothyroidism: radiation dose response and chemotherapeutic radiosensitization at less than 40 Gy. J Surg Oncol 61: 281-283, 1996.

9. Bentzen SM, Constine LS, Deasy JO, et al. Quantitative analyses of normal tissue effects in the clinic (QUANTEC): an introduction to the scientific issues. Int J Radiat Oncol Biol Phys 76: S3-9, 2010. 
10. Cella L, Conson M, Caterino M, et al. Thyroid V30 predicts radiation-induced hypothyroidism in patients treated with sequential chemo-radiotherapy for Hodgkin's lymphoma. Int J Radiat Oncol Biol Phys 82: 1802-1808, 2012.

11. Yoden E, Soejima T, Maruta T et al. Hypothyroidism after radiotherapy to the neck. Nippon Igaku Hoshasen Gakkai Zasshi 64: 146-150, 2004.

12. Joensuu $H$, Viikari J. Thyroid function after postoperative radiation therapy in patients with breast cancer. Acta Oncol 25:167-170, 1986.

13. Reinertsen KV, Cvancarova M, Wist E, et al. Thyroid function in women after multimodal treatment for breast cancer stage II/III: comparison with controls from a population sample. Int J Radiat Oncol Biol Phys 75(3): 764-770, 2009.

14. Bruning P, Bonfrer J, Jong-Bakker MD, et al. Primary hypothyroidism in breast cancer patients with irradiated supraclavicular lymph nodes. Br J Cancer 51: 659-663, 1985.

15. Diaz R, Jaboin JJ, Morales-Paliza M, et al. Hypothyroidism as a consequence of intensity-modulated radiotherapy with concurrent taxane-based chemotherapy for locally advanced head-and-neck cancer. Int J Radiat Oncol Biol Phys 77: 468476, 2010.

16. Vogelius IR, Bentzen SM, Maraldo MV, et al. Risk factors for radiation-induced hypothyroidism. Cancer 117: 5250-5260, 2011.

17. Boomsma JM, Bijl HP, Langendijk JA. Radiation-induced hypothyroidism in head and neck cancer patients: A systematic review. Radiother Oncol 99: 1-5, 2011.

18. Alterio D, Jereczek-Fossa BA, Franchi B, et al. Thyroid disorders in patients treated with radiotherapy for head and neck cancer: a retrospective analysis of seventy-three patients. Int J Radiat Oncol Biol Phys 67: 144-150, 2007.

19. Boomsma MJ, Bijl HP, Christianen ME, et al. A prospective cohort study on radiation-induced hypothyroidism: development of NTCP model. Int J Radiat Oncol Biol Phys 84: e351356, 2012

20. Ronjom MF, Brink C, Bentzen SM, et al. Hypothyroidism after primary radiotherapy for head and neck squamous cell carcinoma: Normal tissue complication probability modeling with latent time correction. Radiother Oncol s109: 317-322, 2013.

21. Cutuli B, Quentin P, Rodier JF, et al. Severe hypothyroidism after chemotherapy and locoregional irradiation for breast cancer. Radiother Oncol 57: 103-105, 2000.
22. Turner SL, Tiver KW, Boyages SC. Thyroid dysfunction following radiotherapy for head and neck cancer. Int J Radiat Oncol Biol Phys 31: 279-283, 1994.

23. Nishiyama K, Kozuka T, Higashihara T, et al. Acute radiation thyroiditis. Int J Radiat Oncol Biol Phys 36: 1221-1224, 1996.

24. Tell R, Sjodin H, Lundell G et al. Hypothyroidism after external radiotherapy for head and neck cancer. Int J Radiat Oncol Biol Phys 39: 303-308, 1997.

25. Sinard RJ, Tobin EJ, Mazzaferri EL, et al. Hypothyroidism after treatment for nonthyroid head and neck cancer. Arch Otolaryngol Head and Neck Surg 126: 652-657, 2000.

26. Posner MR, Ervin TJ, Fabian RL, et al. Incidence of hypothyroidism following multimodality treatment for advanced squamous cell cancer of thehead and neck. Laryngoscope 94: 451-454, 1984.

27. Zidan J, Rubenstein W. Effect of adjuvant tamoxifen therapy on thyroid function in postmenopausal women with breast cancer. Oncology 56: 43-45, 1999.

28. Weissler MC, Berry BW. Thyroid-stimulating hormone levels after radiotherapy and combined therapy for head and neck cancer. Head Neck 13: 420-423, 1991.

\section{Correspondence}

Dr. Serap AKYÜREK

Ankara Üniversitesi Tıp Fakültesi

Radyasyon Onkolojisi Anabilim Dalı

Dikimevi, ANKARA / TURKEY

Tel: (+90.312) 5956285

Fax: (+90.312) 3621495

e-mail: serapak2@gmail.com 